\title{
EFFECT OF AGE AND STAGE OF LACTATION ON THE SIMPLE AND PARTIAL CORRELATIONS BETWEEN THE YIELD AND THE PERCENTAGES OF FAT AND PROTEIN OF COW'S MILK
}

\author{
VAPPU Kossila and Onerva HintikKa \\ Department of Animal Husbandry, University of Helsinki
}

Received Juni 29, 1967

The percentage of protein in cow's milk is positively correlated with the percentage of fat (Andersen \& Langmack 1923, Gaines 1923, Platon \& SJöström 1940, Lonka 1947, Hietaranta \& Niemelä 1954, Peltola et al. 1963). HietaRanta \& Niemelä (1954) and Peltola et al. (1963) found the protein-fat correlation to be all the closer the larger the quantities of milk, for instance in the bulk milk of dairies or in the herd milk as compared to the milk of individual cows. At present it is well known that in individual cows the protein content of milk cannot be satisfactorily estimated on the basis of its fat content. The correlations between these two milk constituents vary greatly in individual cows (KLIESCH et al. 1959) and are affected by age (PIEL 1953, Marckmann \& Witt 1956) and breed (Gaines \& OverMAN 1938) of the cows, the season of the year (KIERmeier \& RenNer 1961, Peltola et al. 1963), the season of calving and the level of milk yield (MARCKMANN \& WiTT 1956), the stage of lactation (PELTOLA et al. 1963) as well as by genetic factors (Bonnier \& Hansson 1946, Hansson \& Bonnier 1949). Moreover, nutritional factors appear to affect somewhat differently the fat and the protein contents of milk (Paloheimo et al. 1955, Jenness \& Patton 1959 pp. 11-12, Kon \& Cowie 1961 pp. 238-240). VAnschoubroek \& Willems (1955) and Kliesch et al. (1959) have investigated the effect of milk yield on the correlation between the contents of fat and protein in cow's milk by means of calculating the coefficients of partial correlation. Most other investigators have presented only the coefficients of simple correlation between the two milk constituents (see KIERMEIER \& RENnER 1961). The purpose of the present study was to gain more information on the extent to which the milk yield affects the correlation between the fat and protein in milk, and on the extent to which the age of cow and/or the stage of lactation influences the coefficients of simple and partial correlations existing between the milk yield and the contents of fat and protein in milk. 


\section{Material and methods}

The present data consists of 1028 milk samples, which were obtained during the years $1953-55$ and $1963-64$ from a total of 70 Ayrshire cows belonging to the dairy herd of the Viik Experimental Farm. All samples were taken during the indoor feeding period. The fat content of the milk was estimated by the Gerber method and the protein content by the Kjeldahl method. The feeding and management of the Viik dairy herd has been described recently in detail by Kossila (1967).

The data were first divided into two groups according to age of cows, i.e. into first-calvers and into cows calved twice or more. Both age-groups were further divided into two sub-classes according to the stage of lactation during which the milk samples were taken, i.e. into the early stage (5-39 days post partum) and the later stages ( $40-360$ days post partum). The cows in the Viik dairy herd have usually reached the peak of lactation by approximately the 40th day post partum. The four first days of lactation were excluded when selecting the data for this study. The simple and partial correlations were calculated according to CROXTON \& CowDEN (1955).

\section{Results}

The coefficients of simple and partial correlations. - The coefficients of simple and partial correlations between the milk yield in $\mathrm{kg}\left(\mathrm{X}_{1}\right)$, and the percentages of fat $\left(\mathrm{X}_{2}\right)$ and protein $\left(\mathrm{X}_{3}\right)$ obtained for the first-calvers, for the older cows, and for all cows between $5-30$ days, between $40-360$ days, and between $5-360$ days post partum, have been summarized in Table 1 . The mean and range values for the daily milk yield and for the percentages of fat and protein, and also the average number of days from the last parturition in the first-calvers as well as in the older cows at both early and later stages of lactation, have been given in Table 2 .

Table 1. The coefficients of simple and partial correlations between the milk yield in $\mathrm{kg}\left(\mathrm{X}_{1}\right)$ and the percentages of fat $\left(\mathrm{X}_{2}\right)$ and protein $\left(\mathrm{X}_{3}\right)$ of milk in the first-calvers, older cows and all cows during early and later stages as well as during the entire period of lactation.

\begin{tabular}{|c|c|c|c|c|c|c|c|c|c|}
\hline & \multicolumn{3}{|c|}{$5-39$ days post partum } & \multicolumn{3}{|c|}{$40-360$ days post partum } & \multicolumn{3}{|c|}{$5-360$ days post partum } \\
\hline & $\begin{array}{c}\text { First- } \\
\text { calvers }\end{array}$ & $\begin{array}{l}\text { Older } \\
\text { cows }\end{array}$ & $\begin{array}{c}\text { All } \\
\text { cows }\end{array}$ & $\begin{array}{c}\text { First- } \\
\text { calvers }\end{array}$ & $\begin{array}{l}\text { Older } \\
\text { cows }\end{array}$ & $\begin{array}{c}\text { All } \\
\text { cows }\end{array}$ & $\begin{array}{c}\text { First- } \\
\text { calvers }\end{array}$ & $\begin{array}{l}\text { Older } \\
\text { cows }\end{array}$ & $\begin{array}{c}\text { All } \\
\text { cows }\end{array}$ \\
\hline $\begin{array}{l}\text { No. of } \\
\text { cases }\end{array}$ & 75 & 340 & 415 & 183 & 430 & 613 & 258 & 770 & 1028 \\
\hline$r_{12}$ & 0.02 & -0.45 & -0.34 & -0.63 & -0.45 & -0.45 & -0.39 & -0.35 & -0.32 \\
\hline $\mathrm{r}_{12.3}$ & 0.34 & -0.33 & -0.22 & -0.11 & -0.17 & -0.15 & 0.06 & -0.15 & -0.12 \\
\hline$r_{13}$ & -0.64 & -0.42 & -0.39 & -0.82 & -0.52 & -0.55 & -0.70 & -0.40 & -0.42 \\
\hline $\mathrm{r}_{13.2}$ & -0.69 & -0.29 & -0.29 & -0.68 & -0.33 & -0.37 & -0.63 & -0.27 & -0.30 \\
\hline$r_{23}$ & 0.36 & 0.42 & 0.41 & 0.72 & 0.65 & 0.66 & 0.61 & 0.57 & 0.57 \\
\hline $\mathrm{r}_{23.1}$ & 0.48 & 0.28 & 0.32 & 0.45 & 0.55 & 0.55 & 0.50 & 0.50 & 0.51 \\
\hline
\end{tabular}


Results in Table 1 indicate that age as well as the stage of lactation of cows had exerted some influence on the investigated simple and partial correlations. The most prominent differences found between the first-calvers and older cows were: a) the dependence of the percentage of fat on the milk yield during early stage of lactation, the correlation between these two factors being positive in the former and negative in the latter, and b) a decidedly stronger negative correlation between the milk yield and the percentage of protein in the former than in the latter. As a whole, the protein content of milk appeared to be more strongly influenced by the level of milk yield than the fat content of milk. The protein-fat correlation was in general less close during the early than during the late stage of lactation (Table 1).

Table 2. The mean and range values of the milk yield and the percentages of fat and protein in milk of the first-calvers and older cows during early as well as during later stages of lactation.

\begin{tabular}{|c|c|c|c|c|c|c|c|c|}
\hline & \multicolumn{4}{|c|}{$5-39$ days post partum } & \multicolumn{4}{|c|}{$40-360$ days post partum } \\
\hline & \multicolumn{2}{|c|}{ First-calvers } & \multicolumn{2}{|c|}{ Older cows } & \multicolumn{2}{|c|}{ First-calvers } & \multicolumn{2}{|c|}{ Older cows } \\
\hline & mean & range & mean & range & mean & range & mean & range \\
\hline Milk yield in $\mathbf{k g}$. & 17.60 & $11.10-23.90$ & 24.20 & $12.50-37.00$ & 15.10 & $4.80-21.70$ & 18.50 & $1.50-35.10$ \\
\hline Fat $\%$ & 4.80 & $3.80-7.20$ & 4.80 & $3.50-7.80$ & 4.60 & $3.50-7.30$ & 4.60 & $2.90-11.00$ \\
\hline Protein \% & 3.67 & $3.08-4.47$ & 3.66 & $2.47-4.80$ & 3.63 & $3.05-4.44$ & 3.55 & $2.33-7.06$ \\
\hline $\begin{array}{c}\text { Days post partum } \\
\text { on an average }\end{array}$ & & 21 & & 15 & & 156 & & 142 \\
\hline
\end{tabular}

With exception of the first-calvers at early stages of lactation, all partial coefficients of correlation obtained from the present data were lower than the corresponding simple correlations. Thus for instance, the protein-fat correlation was diminished when the milk yield was taken into consideration (Table 1). Although the older cows produced considerably more milk, on an average, than the first-calvers, the mean percentages of fat and protein of milk were quite similar in both age-groups (Table 2).

Table 3. Percentage of the variation in the dependent variable that was explained by the variations in the independent variables.

\begin{tabular}{|c|c|c|c|c|c|c|c|c|c|}
\hline \multirow[t]{2}{*}{ Dependent variable } & \multicolumn{3}{|c|}{$5-39$ days $p . p}$. & \multicolumn{3}{|c|}{$40-360$ days $p \cdot p$} & \multicolumn{3}{|c|}{$5-360$ days $p . p$. } \\
\hline & $\begin{array}{l}\text { First- } \\
\text { calvers }\end{array}$ & $\begin{array}{l}\text { Older } \\
\text { cows }\end{array}$ & $\begin{array}{c}\text { All } \\
\text { cows }\end{array}$ & $\begin{array}{c}\text { First- } \\
\text { calvers }\end{array}$ & $\begin{array}{l}\text { Older } \\
\text { cows }\end{array}$ & $\begin{array}{c}\text { All } \\
\text { cows }\end{array}$ & $\begin{array}{l}\text { First- } \\
\text { calvers }\end{array}$ & $\begin{array}{l}\text { Older } \\
\text { cows }\end{array}$ & $\begin{array}{c}\text { All } \\
\text { cows }\end{array}$ \\
\hline Milk yield in $\mathrm{kg}\left(\mathrm{X}_{1}\right)$ & 47.96 & 26.81 & 18.94 & 67.52 & 28.71 & 31.30 & 49.34 & 18.34 & 18.85 \\
\hline Fat $\%\left(\mathrm{X}_{2}\right)$ & 23.39 & 26.64 & 20.88 & 52.39 & 44.33 & 44.09 & 36.85 & 34.46 & 33.76 \\
\hline Prot. $\%\left(\mathrm{X}_{\mathrm{a}}\right)$ & 54.71 & 24.49 & 23.66 & 73.92 & 50.02 & 50.71 & 62.09 & 37.67 & 39.07 \\
\hline
\end{tabular}


The percentage of explained variation. - Results summarized in Table 3 demonstrate that the percentage of variation in the dependent variable, i.e. either the milk yield, the percentage of fat, or the percentage of protein, that was explained by the variations in the independent variables, i.e. simultaneously by the variations in $X_{2}$ and $X_{3}, X_{1}$ and $X_{3}$, or $X_{1}$ and $X_{2}$, respectively, was influenced by age of the cows as well as by the stage of lactation. The percentage of variation in the milk $\mathrm{y}$ i e ld that was explained by the variations in the contents of fat and protein, was affected more by the age of the cow than by the stage of lactation (Table 3). In the first-calvers it was 47.96 during the early phases and 67.52 during the late phases of lactation. Corresponding values, 26.81 and 28.71, obtained for older cows were markedly lower. The percentage of variation in the $\mathrm{f}$ a $\mathrm{t}$ content of milk that was explained by the variations in the milk yield and the protein content of milk, was influenced more by the stage of lactation than by the age of the cow. It was lower during the early stages of lactation than during the later stages, the corresponding values obtained for all cows being 20.88 and 44.09 . On the other hand, the percentage of variation in the p r o t e in content of milk that was explained by the variations in milk yield and the fat content, was influenced by the age of the cows as well as by the stage of lactation. It was higher in the first-calvers during early (54.71) as well as during late (73.92) stages of lactation than in older cows (24.49 and 50.02), and, as these figures demonstrate, it was lower in both age-groups of cows during the early stages of lactation than during the late stages (see Table 3).

The estimating equations. - The equations, obtained separately from the present data for the first-calvers and for the older cows during early stages (5-39 days post partum) (A) and during later stages (40-360 days post partum) (B) of lactation as well as during the entire period (5-360 days post partum) $(\mathrm{A}+\mathrm{B})$ of lactation, for estimating theoretically the daily milk yield in $\mathrm{kg}\left(\mathrm{X}_{\mathrm{c}_{1} \cdot 23}\right)$, the percentage of fat $\left(\mathrm{X}_{\mathrm{c} 2 \cdot 13}\right)$, or the percentage of protein $\left(\mathrm{X}_{\mathrm{c} 3 \cdot 12}\right)$, when any two out of the three variables $\left(\mathrm{X}_{1}, \mathrm{X}_{2}, \mathrm{X}_{3}\right)$ in question are known, have been summarized in Table 4. The equations demonstrate the relative effect of two variables at a time on the third variable in both age-groups of animals during early, late, and the entire period of lactation.

\section{Discussion}

The data of the present study were obtained during the indoor feeding period from a well-fed and high-producing Ayrshire herd. Therefore the results presented in this paper are not necessarily applicable as such to conditions that differ considerably from those of the Viik dairy herd.

The percentage of fat usually decreases with an increase in the milk yield, though there may be some exceptions to this rule (KLIESCH et al. 1959). PIEL (1953) obtained a correlation, $\mathrm{r}_{12}=-0.48$, between the milk yield and the fat content of milk for the first-calvers. In the present study the respective simple correlation, $r_{12}=0.02$, obtained for the first-calvers at an early stage of lactation, was negligible (Table 1). On the other hand, the corresponding partial correlation, which was found when the protein content of milk was held constant, was decidedly positive, $r_{12 \cdot 3}=0.34$. 
This result was somewhat unexpected. Older cows had correspondingly negative correlations $\left(r_{12}=-0.45\right.$ and $\left.r_{12 \cdot 3}=-0.33\right)$ (Table 1). Heifers of the Viik herd have usually been in very good condition at their first parturition. Thus it is possible that they were able to mobilize somewhat more effectively than older cows fatty acids from their body deposits using them as precursors of milk fat. Moreover, the first-calvers had lower average milk yield and also a narrower range of variation in their percentage of milk fat at the early stage of lactation than older cows (Table 2), and these factors have possibly exerted some influence on the coefficients of the correlation in question. However, during later stages of lactation, the milk yield had a negative effect on the fat content of milk in the first-calvers as well as in the older cows; the simple correlation was larger in the former $\left(r_{12}=-0.63\right)$ than in the latter $\left(r_{12}=-0.45\right)$ (Table 1), in spite of the fact that the range of the values of the milk yield and the percentage of fat was wider in the latter (Table 2). The partial coefficients of correlation obtained between the milk yield and the percentage of fat $\left(\mathrm{r}_{12 \cdot 3}\right)$ revealed, however, that in both age-groups of cows at late stages of lactation, the milk yield had a relatively small effect on the fat content of milk when the protein level was held constant (Table 1) (see also equations in Table $4)$.

The protein content in milk of the first-calvers appeared to be more strongly affected by the level of milk yield throughout the period of lactation than was the case with older cows (Table 1). The negative correlation between the milk yield and the protein content in the milk of first-calvers was stronger in the present data, i.e. $\mathrm{r}_{13}=-0.64$ at an early stage, -0.82 at a later stage and -0.70 during the entire period of lactation (Table 1) than the correlation, - 0.54, obtained by PIEL (1953) for first-calvers. The latter, however, produced only $9.84 \pm 0.097 \mathrm{~kg}$ milk on an average per day (cf. corresponding values in Table 2).

The partial coefficients of correlation, obtained between the milk yield and the protein content of milk when the fat content was held constant $\left(r_{13 \cdot 2}\right)$, were in all cases, except in the first-calvers at early stages of lactation, lower than the respective simple correlations (Table 1). It was found that even when the percentage of fat was held constant, the milk yield still appeared to have a significant negative effect on the percentage of protein this effect being largely independent of the effect of the percentage of fat (Table 1).

The milk yield as well as the protein content of milk depends to a certain degree upon the total amounts of energy and crude-protein in the ration. Insufficiency of total energy and/or protein in the ration has a depressing effect on the milk yield as well as on the protein content of milk (BREIREM 1949, Paloheimo et al. 1955, Felinski 1962, Davidov \& Gal'ceva 1963, Becker et al. 1965). According to PiATKOWSKI (1965), the retention of nitrogen of heifers during the last 8 weeks of gestation has a marked effect on their milking performance at the beginning of the subsequent lactation. Piatkowski suggests that since heifers have a comparatively small food capacity, they should be fed high-quality basal foodstuffs to meet their requirements. Overfeeding of crude protein, however, does not apparently result in a higher production of milk or a higher percentage of protein (HARRISON \& SAVAGE 1932). In fact, an excess of crude protein in the ration may interfere with the produc- 
tion of volatile fatty acids in the rumen through rapid formation and release of ammonia from nitrogen-containing substances by rumen micro-organisms. In consequence, the $\mathrm{pH}$ of the rumen contents may rise above the optimum leading to a decrease in the overall efficiency of the rumen function. Heavy overfeeding of crude protein may also interfere with a normal liver function and result in kidney damage leading to a state of nutritional stress (ref. SAARINEN 1957, BARNETT \& REID 1961 pp. $110-114,127-128$, Scheunert \& Trautmann 1965 pp. 278-279). At present it is doubtful whether a further increase in the contents of total energy and crude protein in the pre- and/or post partum rations of the first-calvers in the Viik dairy herd would be beneficial in preventing the protein content from decreasing with an increasing milk yield to the extent that was observed in the present study, because the nutritional conditions of the Viik dairy herd are already very good, and the cows have received a level of crude protein that has been considerably above the recommended standards. In the Viik herd, the heifers have been bred to calve at the age of $26-28$ months, and the cows complete their growth by 5 years of age. It may be possible that since the first-calvers continue to grow during their first period of lactation, the amino-acids circulating in their blood are intensively taken up by growing body tissues and this process may compete with the synthesis of milk protein in the mammary gland.

The percentage of fat in milk was found to vary to a wider degree than the percentage of protein respectively (Table 2). This finding is in accordance with the observations of KIERMEIER \& RENNER (1961), who investigated 6846 milk samples taken from individual cows. Even though older cows in the present data produced more milk on an average than the first-calvers, the mean levels of fat and protein in milk were similar in both groups (Table 2). The udder volume and the number of milk-secreting alveoli in the mammary gland usually increase with age up to the 4 th-6th calvings, while there is a simultaneous increase in the gross capacity of the mammary gland to secrete milk and its constituents. Thus a high daily milk yield does not necessarily need to be associated with low contents of protein and fat in milk, if the nutritional requirements of the lactating cows are satisfied.

The protein-fat correlation was found to be less close during the early than during the later stages of lactation (Table 1). This result is in agreement with the observations of Lonka (1952) 1 and Peltola et al. (1963). The age of the cows did not appreciably affect the protein-fat correlation in the present data. MARCKMANN \& WITT (1956) obtained slightly closer correlation for the first-calvers $\left(r_{23}=+0.68\right)$ than correspondingly for cows than had calved more than twice $\left(r_{23}=+0.61\right)$ (cf. Table 1). As a whole, the coefficients of simple correlation between the contents of fat and protein in milk are in accordance with the majority of the results published earlier (see KIERMEIER \& RENNER 1961).

The partial coefficients of correlation obtained between the contents of fat and protein while the milk yield was held constant $\left(\mathrm{r}_{23 \cdot 1}\right)$ were lower than the corresponding simple correlations in the present study except in the first-calvers at early stage of lactation (Table 1). These results indicated, that the milk yield had influenced the

1) LoNKA (1952) investigated the casein-fat correlations. 
protein-fat correlation. It seems, however, that the major part of the protein-fat correlation has been independent of the variations in the milk yield. For instance, in all cows during the entire period of lactation, the partial correlation, $r_{23 \cdot 1}=0.51$, was not significantly smaller than the respective simple correlation, $r_{23}=0.57$ (Table 1). This tendency is in agreement with the results of KLIESCH et al. (1959), who obtained correspondingly the simple and partial correlations, $r_{23}=0.51$ and $\mathrm{r}_{23 \cdot 1}=0.47$. Moreover, Kliesch et al. found that the partial correlation varied from -0.43 to +0.87 in individual cows, which indicated that the protein content of milk could not be reliably estimated on the basis of its fat content or vice versa. Contradictory to the results of the present study and those of Kliesch et al., VANSchoubroEK \& Willems (1955) found that the fat-protein correlation increased slightly when the level of the milk yield was held constant $\left(r_{23}=0.288\right.$ and $r_{23 \cdot 1}=$ $0.291)$.

The percentage of explained variation in the dependent variable appears to rise when the number of independent variables is increased. Thus, for instance, the protein content of milk could be more closely estimated on the basis of the fat content and the milk yield than on the basis of the fat content alone, particularly since the milk yield appears to have a more marked effect on the protein content than on the fat content (Table 1). The highest percentage of variation in the dependent variable, the protein content of milk $\left(\mathrm{X}_{3}\right)$, that was explained simultaneously by two independent variables, i.e. by the milk yield $\left(\mathrm{X}_{1}\right)$ and by the percentage of fat $\left(\mathrm{X}_{2}\right)$, was the one (73.92) obtained tor the first-calvers at later stages of lactation (Table 3); respectively the variation in $\mathrm{X}_{3}$ explained by $\mathrm{X}_{2}$ alone was 51.83 only. The percentage of variation in the investigated dependent variables that was explained by the variations in the independent variables (Table 3), was in most cases very low indicating that the milk yield and the contents of fat and protein vary to a great extent independently of each other.

The estimating equations in Table 4, obtained separately for the $\mathrm{f}$ i r s t c a lvers and older cow s at early (A) and late (B) stages as well as during

Table 4. The estimating equations obtained from the data of first-calvers and from those of older cows during early (A) as well as during later (B) stages and during the whole period (A $+\mathrm{B})$ of lactation. Detailed explanation in text.

\begin{tabular}{|c|c|c|}
\hline & First-calvers & Older cows \\
\hline A & $\mathrm{X}_{\mathrm{c} 1.23}=32.2840+1.3346 \mathrm{X}_{2}-5.7466 \mathrm{X}_{3}$ & $\mathrm{X}_{\mathrm{c} 1.23}=43.6413-2.0311 \mathrm{X}_{2}-2.6481 \mathrm{X}_{3}$ \\
\hline B & $\mathrm{X}_{\mathrm{c} 1.2 \mathrm{~s}}=46.9488-0.4965 \mathrm{X}_{2}-8.1446 \mathrm{X}_{\mathrm{s}}$ & $\mathrm{X}_{\mathrm{c} 1.23}=46.0098-2.0139 \mathrm{X}_{2}-5.1397 \mathrm{X}_{3}$ \\
\hline A & $\mathrm{X}_{\mathrm{c} 2.13}=-0.5565+0.0887 \mathrm{X}_{1}+1.0343 \mathrm{X}_{3}$ & $\mathrm{X}_{\mathrm{c} 2.13}=4.5459-0.0539 \mathrm{X}_{2}+0.4258 \mathrm{X}_{3}$ \\
\hline B & $\mathrm{X}_{\mathrm{c} 2.13}=0.6717-0.0231 \mathrm{X}_{1}+1.1782 \mathrm{X}_{3}$ & $\mathrm{X}_{\mathrm{c} 2.13}=2.3245-0.0140 \mathrm{X}_{1}+0.7141 \mathrm{X}_{3}$ \\
\hline A & $4.0584-0.0834 \mathrm{X}_{1}+0.2250 \mathrm{X}_{2}$ & $\mathrm{X}_{\mathrm{c} 3.12}=3.5071-0.0313 \mathrm{X}_{1}+0.1896 \mathrm{X}_{2}$ \\
\hline B & $\mathrm{X}_{\mathrm{c} 3.12}=3.6746-0.0563 \mathrm{X}_{1}+0.1751 \mathrm{X}_{2}$ & $\mathrm{X}_{\mathrm{c} 3.12}=1.9809-0.0214 \mathrm{X}_{1}+0.4270 \mathrm{X}_{2}$ \\
\hline $\mathrm{A}+\mathrm{B}$ & $\mathrm{X}_{\mathrm{c}_{1} \cdot 23}=41.9811+0.2911 \mathrm{X}_{2}-7.5685 \mathrm{X}_{3}$ & $\mathrm{X}_{\mathrm{c} 1.2 \mathrm{~s}}=42.3449-1.6858 \mathrm{X}_{2}-4.0060 \mathrm{X}_{3}$ \\
\hline $\mathbf{A}+\mathbf{B}$ & $0.1472+0.0116 \mathrm{X}_{1}+1.2005 \mathrm{X}_{3}$ & $\mathrm{X}_{\mathrm{c} 2.13}=2.4949-0.0140 \mathrm{X}_{1}+0.6905 \mathrm{X}_{3}$ \\
\hline $\mathrm{A}+\mathrm{B}$ & $\mathrm{X}_{\mathrm{c} 3.12}=3.4836-0.0531 \mathrm{X}_{1}+0.2117 \mathrm{X}_{2}$ & $\mathrm{X}_{\mathrm{c} 3.12}=2.2224-0.0178 \mathrm{X}_{1}+0.3690 \mathrm{X}_{2}$ \\
\hline
\end{tabular}


the entire period of lactation $(\mathrm{A}+\mathrm{B})$, demonstrate the relative effect of two investigated variables at a time on the third variable. It must be borne in mind that the equations in Table 4 are based on material collected from a well-fed and highproducing Ayrshire herd during their in d o o r feeding period. The equations in. Table 4 which have been given for the estimation of the theoretical protein content of the milk $\left(\mathrm{X}_{\mathrm{c3} \cdot 12}\right)$ when the milk yield $\left(\mathrm{X}_{1}\right)$ and the percentage of fat $\left(\mathrm{X}_{2}\right)$ are known, obviously give closer estimates for the protein in milk than equations that are based on the variations of fat alone. However, it seems that several rapid dyebinding methods, e.g. the Pro-Milk method, give much closer estimates for the milk protein than any equations presented in Table 4 (Kossila 1964). The interrelationships between the milk yield and the contents of fat and protein are affected by somany factors that under practical conditions it is nearly impossible to consider them all at the same time. For instance, Vanschoubroek \& Willems (1955) presented an equation:

$$
\mathrm{X}_{\mathrm{c} 3 \cdot 12}=2.411+0.1644 \mathrm{X}_{2}+0.00053 \mathrm{X}_{1}
$$

for estimating the protein content of milk on the basis of the percentage of fat and the milk yield (in litres). The symbols of the above equation were changed from the original form to correspond to those used in the present study. In the data of Vanschoubroek \& Willems, the milk yield appeared to have practically no effect on the protein content of milk, which result is not in agreement with the results of the present study (see Table 4).

\section{Summary}

Coefficients of simple and partial correlations between the milk yield and the percentages of fat and protein in milk were calculated separately for the first-calvers and older cows during the early period of lactation (5-39 days post partum), during a later period ( $40-360$ days p.p.), and during the entire period of lactation, from the data of 1028 milk samples obtained during the indoor-feeding period from 70 different Ayrshire cows belonging to the Viik Experimental Farm dairy herd. Statistical treatment of the data revealed that the milk yield affected the protein content of the milk more than its fat content, especially in the first-calvers. The protein-fat correlation, which was somewhat affected by the milk yield, was generally less close during the early stage of lactation than during its later stage.

The percentage of variation in a) the $\mathrm{milk} \mathrm{y}$ i e l d that was explained by the variations in the percentage of fat and protein, was affected more by age than by the stage of lactation, b) the $\mathrm{f}$ a t content of milk that was explained by the variations. in the milk yield and the protein content of milk, was influenced more by the stage of lactation than by the age of the cow, c) the prot e in content of milk that was. explained by the variations in milk yield and the fat content, was influenced by ageas well as by stage of lactation.

The equations for estimating theoretically the daily milk yield, the percentage of fat, or the percentage of protein in milk, when two out of the three variables are known, have been presented separately for the first-calvers and for the older cows. at early and at later stages as well as during the entire period of lactation. The results. 
of the study indicated that the milk yields and the percentages of fat and protein in milk vary to such an extent independently of each other, even when the age of cows, the stage of lactation, and the season of the year have been taken into consideration, that none of the dependent variables in question could be very closely estimated on the basis of knowing two of the independent variables.

\section{REFERENCES}

Andersen, A. G. \& LANGMack, P. V. F. P. 1923. Undersøgelser over den danske komaeks genomsnittelige sammansaetning. Beretn. fra Forsøglaboratoriet 113: 1-38.

Barnett, A. J. G. \& ReID, R. L. 1961. Reactions in the rumen. Edward Arnold, London VII +252 pp. (pp. $110-114)$.

Becker, R. B., Arnold, P. T. D., Wilcox, C. J., Krienke, W. A., Mull, L. E., Fonts, E. L. 1965. Subnormal milk-cause and correction. Bull. Fla. Agr. Exp. Sta. 692, 36 pp.

Bonnier, G. \& Hansson, A. 1946. Studies on monozygous cattle twins. VII. On the genetical determination of the interdependency between the percentage of fat, protein, and lactose in the milk. Acta Agr. Suec. 2: 171-184.

BREIREM, K. 1949. The influence of feeding on the composition of milk and on the quality of dairy products. 12th Int. Dairy Congr., Stockholm 6: 9-28.

Croxton, F. E. \& Cowden, D. J. 1955. Applied general statistics. 2nd ed. London XVI +843 pp. (Chapter 21).

Davidov, R. \& GaL'ceva, V. 1963. Variations in the amount and composition in milk. Mol. Prom. no. 10: 8-11. (ref. Nutr. Abstr. \& Revs. 34: 2 ab. 2070).

FELINSKI, L. 1962. Urea and ammonia replacing part of the protein in feeds for ruminants. Soc. Sci. Stetin., Wydz. Nauk Przyrod.-Rol. 8: 2: 52.

Gaines, W. L. 1923. Relative rates of secretion of various milk constituents. J. Dairy Sci. 8: 486-496.

- \& Overman, O. R. 1938. Interrelations of milk-fat, milk-protein and milk-energy yield. Ibid. 21: $261-271$.

HAnsson, A. \& Bonnier, G. 1949. Further studies on the genetical determination of the composition of cow's milk with regard to fat, protein and lactose. Acta Agr. Suec. 3: 179-188.

Harrison, E. S. \& Savage, E. S. 1932. The effect of different planes of protein intake upon milk production. Cornell Univ. Agr. Expt. Sta. Bull. 504.

Hietaranta, M. \& Niemelä, K. 1954. Rasva- ja valkuaispitoisuuden suhteesta suomalaisessa maidossa. J. Sci. Agr. Soc. Finland 26: 148-158.

Jennes, R. \& PAtton, S. 1959. Principles of dairy chemistry. John Wiley \& Sons, Inc. London VIII + 446 pp. (pp. 11-12).

Kiermeier, F. \& RenNer, E. 1961. Uber das Verhältnis des Eiweissgehaltes der Milch zum Fettgehalt und dessen Bedeutung für die Züchtung. Züchtungskunde 33: 32-43.

Kliesch, J., Neuhaus, U. \& Horst, P. 1959. Untersuchungen über die Schwankungen des Eiweiss- und Fettgehaltes im Verlauf der Laktation und über die Beziehungen zwischen Eiweissgehalt, Fettgehalt und Milchmenge. Ibid. 31: 18-27.

Kon, S. K. \& CowIE, A. T. 1961. Milk: the mammary gland and its secretion. Vol. II. Acad. Press, New York. pp. $238-240$.

KossıLA, V. 1964. Kokeiluja Pro-Milk-laitteen soveltuvuudesta maidon valkuaispitoisuuden määrittämiseen. Karjantuote 47: 655-657.

- 1967 . On the weight and basic structural components of the thyroid in dairy cattle. Acta Agr. Fenn. 109: 2 pp. 32-36.

LoNKA, T. 1947. Can the relation between fat and protein in milk be changed by selective breedin?g J. Sci. Agr. Soc. Finland 19: 8-13.

-1 1952. The relation between fat and protein in milk. Ibid. $24: 176-181$, 
Marckmann, E. \& Witr, W. 1956. Der Eiweissgehalt der Milch in Beziehung zur Milchmenge, zum Fettgehalt, zum Kalbeszeitpunkt, zum Laktationsverlauf und zum Alter der Kühe. Z. Tierzucht. u. Züchtungsbiol. 68: 23.

Paloheimo, L., Неrкola, E. \& Mãkelä, A. 1955. Studies on the composition of cow's milk. Acta Agr. Fenn. 83: 113-124.

Peltola, E., Antila, P. \& Mä́ккі, Y. 1963. Tutkimuksia suomalaisen lehmänmaidon koostumuksesta. Meijeritiet. Aikak. kirja 24: 3-18.

Piatкowsкi, B. 1965. Protein metabolism in late stages of pregnancy in twin heifers reared on different planes. Arch. Tierernähr. 15: 135-146.

Piel, H. 1953. Die Wechselbeziehungen von Milchmenge, Fett- und Eiweissgehalt bei Braunviehfärsen. Züchtungkunde 24: 266-279.

Platon, B. \& S öström, G. 1940. Den svenska mejerimjölkens sammansättning. Meddelande Statens Mejeriförsök 4: $36-39$.

SAARINEN, P. 1957. On the detrimental effects of protein overfeeding on pasture. Maatal. ja Koetoim. 11: $52-61$.

Scheunert, A. \& Trautmann, A. 1965. Lehrbuch der Veterinär-Physiologie. 5. Aufl. Paul Parey, Berlin, XVI $+848 \mathrm{~S}$.

VAnschoubroek, F. \& Willems, A. E. R. 1955. The genetic variation of total protein content in relation to fat content of cow's milk. Zootecnia, Madrid 4: 2: 76-88. (ref. D.S.A. 1955, 17: 693).

\author{
SEL OST U S
} LAKTAATIOKAUDEN VAIHEEN VAIKUTUKSESTA TUOTETUN MAITOMÄ R RN JA MAI-
DON RASVA- JA VALKUAISPROSENTTIEN VALISIIN YKSINKERTAISIIN JA OSITTAIS-
VUOROSUHTEISIIN ENSIKOILLA JA USEAMMAN KERRAN POIKINEILLA LEHMILLA

\author{
Vappu Kossila ja Onerva Hintikka \\ Helsingin yliopiston kotieläintieteen laitos
}

Tuotetun maitomäärän ja maidon rasva- ja valkuaisprosenttien väliset yksinkertaiset ja osittaisvuorosuhteet laskettiin erikseen ensikoille ja useamman kerran poikineille lehmille sekä heruma- että ehtymäkautena kuin myös koko laktaatiokautena. Tarkasteltavana oleva aineisto käsitti yhteensä 1028 maitonäytettä, jotka oli kerätty Viikin opetus- ja koetilan Ayrshirerotuisesta lypsykarjasta. Aineiston tilastollisessa tarkastelussa kävi ilmi, että päivittäin tuotettu maitomäärä oli kiinteämmässä vuorosuhteessa maidon valkuais- kuin rasvaprosenttiin varsinkin ensikkolehmillä. Rasva- ja valkuaisprosenttien välinen vuorosuhde, joka oli jonkinverran kiinteămpi ehtymä- kuin herumakautena, näytti jossain määrin riippuvan tuotetusta maitomäärästä (Taulukko 1).

Se osa maitotuotoksen vaihteluista, joka pystyttiin selittämään rasva- ja valkuaisprosenttien vaihteluilla, riippui enemmän lehmän iästä kuin laktaatiokauden vaiheesta; se osa rasvaprosentin vaihteluista, joka pystytiin selittämään tuotetun maitomäärän ja maidon valkuaisprosentin vaihteluilla, riippui enemmän laktaatiokauden vaiheesta kuin lehmän iästä; se osa valkuaisprosentin vaihteluista, joka pystyttiin selittämään tuotetun maitomäärän ja maidon rasvaprosentin vaihteluilla, riippui selvästi sekä laktaatiokauden vaiheesta että lehmän iästä (Taulukko 3 ).

Tuotetun maitomäärän ja maidon rasva- ja valkuaisprosenttien välisiä riippuvuussuhteita kuvaavat yhtälöt on esitetty erikseẹn ensikoille ja useamman kerran poikineille lehmille sekä heruma- että ehtymäkautena kuin myös koko laktaatiokautena (Taulukko 4). Tutkimuksessa todettiin, että vaikka laktaatiokauden vaiheen, lehmän iän sekä vuodenajan vaikutukset oli pyritty suureksi osaksi eliminoimaan, vaihtelivat tuotettu maitomäärä ja maidon rasva- ja valkuaisprosentit siinä määrin toisistaan riippumatta, että mitään kulloinkin riippuvana muuttujana pidettävää tekijää ei voitu luotettavasti määrittää kahden muun riippumattomana pidetyn tekijän avulla. 